FRENCH FILM DIRECTORS
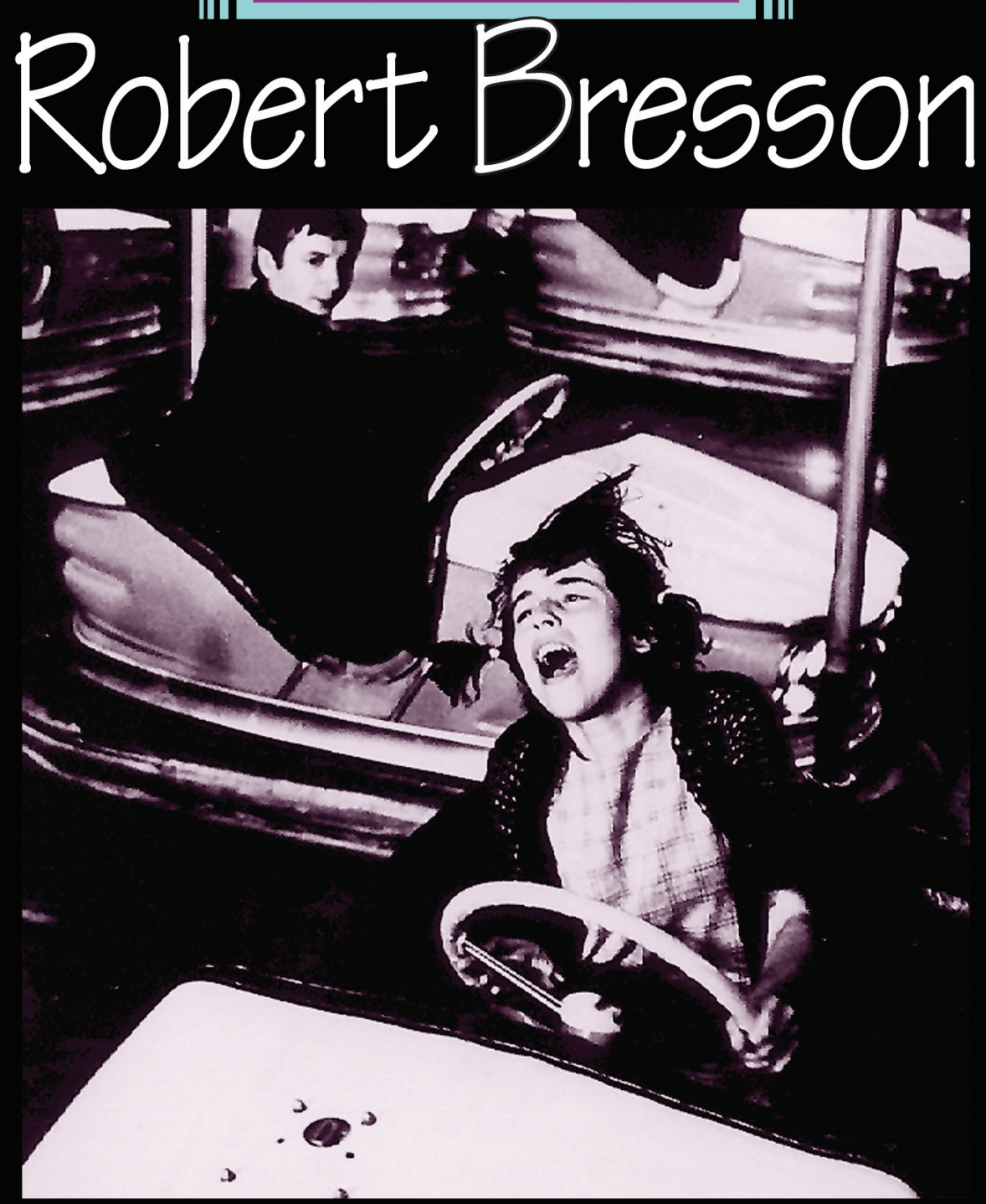

KEITH READER 


\section{Robert Bresson}

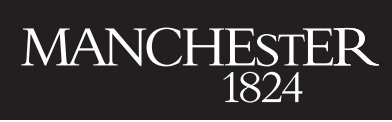

Manchester University Press 


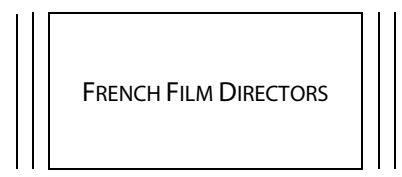

DIANA HOLMES and ROBERT INGRAM series editors DUDLEY ANDREW series consultant

LUC BesSON SUSAN HAYWARD

Claude Chabrol GUY AUSTIN

Diane Kurys CARRIE TARR

George Méliès ELIZABETH EZRA

Coline Serreau BRIGITTE ROLLET

François Truffaut DIANA HOLMES AND ROBERT INGRAM

Agnès Varda ALISON SMITH

forthcoming titles

Jean-Jacques Beineix PHIL POWRIE

Bertrand Blier SUE HARRIS

Jean Cocteau JAMES WILLIAMS

Marguerite Duras RENATE GUNTHER

Jean-Luc Godard STEVE CANNON AND ELIANE MEYER

Jean Renoir MARTIN O'SHAUGHNESSY

Bertrand Tavernier LYNN A. HIGGINS

André Teclimé BILL MARSHALL

Jean Vigo MICHAEL TEMPLE 
FRENCH FILM DIRECTORS

\title{
Robert Bresson
}

\author{
KeItH READER
}

Manchester University Press

MANCHESTER AND NEW YORK 
Copyright (C) Keith Reader 2000

The right of Keith Reader to be identified as the author of this work has been asserted by him/her in accordance with the Copyright, Designs and Patents Act 1988.

Published by Manchester University Press

Altrincham Street, Manchester M1 7JA, UK

www.manchesteruniversitypress.co.uk

British Library Cataloguing-in-Publication Data

A catalogue record for this book is available from the British Library

Library of Congress Cataloging-in-Publication Data

A catalog record for this book is available from the Library of Congress

ISBN 0719053668 paperback

First published 2000

The publisher has no responsibility for the persistence or accuracy of URLs for any external or third-party internet websites referred to in this book, and does not guarantee that any content on such websites is, or will remain, accurate or appropriate. 